\title{
Gonadal Maturation in Pseudoplatystoma metaense $\times$ Leiarius marmoratus Hybrids, (Siluriformes: Pimelodidae)
}

\author{
Maduración Gonadal en Híbridos de Pseudoplatystoma metaense \\ $\times$ Leiarius marmoratus (Siluriformes: Pimelodidae)
}

José Rodriguez-Pulido'; Jonathan Villamil-Rodriguez ${ }^{2}$; Tatiana Mira-López ${ }^{3}$; Pablo Cruz-Casallas ${ }^{4} \&$ Bernardo Baldisserotto $^{5}$

\begin{abstract}
RODRIGUEZ-PULIDO, J.; VILLAMIL-RODRIGUEZ, J.; MIRA-LÓPEZ, T.; CRUZ-CASALLAS, P. \& BALDISSEROTTO, B. Gonadal maturation in Pseudoplatystoma metaense $\times$ Leiarius marmoratus hybrids, (Siluriformes:Pimelodidae). Int. J. Morphol., 38(5):1405-1411, 2020.
\end{abstract}

SUMMARY: Establishing guidelines for responsible management in fish production systems requires knowledge of the basic biology of the fish to be raised. The objective of this work was to determine the reproductive capacity of hybrids produced from the crossing of females of Pseudoplatystoma metaense with males of Leiarius marmoratus. Males presented a digitiform, unrestricted spermatogonial testicle containing caudal digits producing glycoproteins that do not form a seminal vesicle. It was possible to find free sperm in the lumen of the tubules and in the ducts. The ovary of the females was found to be saccular and synchronous with at least three groups of oocytes. In the first year of life, only oogonia up to previtellogenic oocytes (cortical alveolus $284.9 \pm 35.7 \mathrm{~mm}$ in diameter) were found. After the second year vitellogenic oocytes $730 \pm 3.78 \mathrm{~mm}$ in diameter were observed. The events of gonadal development of the hybrids indicate that they are gonochoric, synchronic animals. The maturation peaks in the high-water season, overlapping with the parental species. Therefore, the escape of hybrids from fish cultures to the rivers may increase the risk of crosses, gene introgression, or diminution of the reproductive capacity of the pure species.

KEY WORDS: Gonadal development; Indices; Sexual maturation.

\section{INTRODUCTION}

Generally, hybridisation is reported as a common event of species, with an incidence between 4 and $5 \%$, and is a source of genetic variability and evolutionary basis (Mallet, 2005). In lacustrine environments, it is estimated that $6-10 \%$ of inter-species crosses are hybrids (do Prado et al., 2012). It has also been suggested that hybrids present a source of genetic disparity between lineages (Melo et al., 2018). Hybrids are frequently used in commercial aquaculture, as they may offer increased commercial performance, resistance to diseases and tolerance to extreme conditions which are not seen in the parental species. For example, the hybrid catfish of Clarias gariepinus x $C$. microcephalus presents better growth and disease resistance (Hashimoto et al., 2011), increased meat quality (Alves et al., 2014) and is considered more adaptable to variations in pond conditions than the parent species (Dunham et al., 2014; Zhang et al., 2016). The use of crosses and hybrid production is common practice with ornamental species to produce variations in shape and colour (Bartley et al., 2000). It has recently been found that hybrids of Siluriformes accept commercial feed and exhibit higher growth rates and lower cannibalism than the parent species (Dunham et al.). Among the South American countries, Brazil and Colombia have implemented the cultivation of hybrids without analysing

\footnotetext{
${ }^{1}$ Programa de Doctorado Ciencias Agrarias, Facultad de Ciencias Agrarias y Recursos Naturales, Instituto de Acuicultura de los Llanos, GRITOX, Universidad de los Llanos. Km 4 vía Puerto López, Villavicencio, Meta, Colombia. https://orcid.org/0000-0002-6735-3885

${ }^{2}$ Posgrado en Acuicultura, Instituto de Acuicultura de los Llanos, GRITOX, Universidad de los Llanos. Km 4 vía Puerto López, Villavicencio, Meta, Colombia. jonafe.villamil@gmail.com, https://orcid.org/0000-0002-8767-8580

${ }^{3}$ Facultad de Ciencias Agropecuarias y Recursos Naturales, Instituto de Acuicultura de los Llanos, GRITOX, Universidad de los Llanos. Km 4 vía Puerto López, Villavicencio, Meta, Colombia.tmira@unillanos.edu.co, https://orcid.org/0000-0002-2278-7997

${ }^{4}$ Facultad de Ciencias Agropecuarias y Recursos Naturales, Instituto de Acuicultura de los Llanos, GRITOX, Universidad de los Llanos. Km 4 vía Puerto López, Villavicencio, Meta, Colombia. pecruzcasallas@unillanos.edu.co, https://orcid.org/0000-0003-4641-1692

${ }^{5}$ Departamento de Fisiologia e Farmacologia, Universidade Federal de Santa Maria, 91705-900 Santa Maria, RS, Brazil. bbaldisserotto@ hotmail.com, https://orcid.org/0000-0002-8770-0100
} 
the risks involved (Hashimoto et al.; Alves et al.; RodríguezPulido et al., 2016). However, their escape from flooded aquaculture facilities has been registered (do Prado et al.). Viable hybrids can interbreed with parental species and may compromise the viability of native populations and the genetic diversity (Lima et al., 2018a,b). The aim of the present study was to evaluate the reproductive viability and factors that influence gonadal maturation of the hybrids resulting from the crossing of Pseudoplatystoma metaense and Leiarius marmoratus.

\section{MATERIAL AND METHOD}

Hybrid production and cultivation. Mature breeders of $P$. metaense (females, voucher MHNU-1-1357) and $L$. marmoratus (males, voucher MHNU-1-1358) maintained at a stocking density of $0.204 \mathrm{~kg} / \mathrm{m}^{2}$ in the Primavera Aquaculture farm located in the city of Guamal (Meta, Colombia) were used to obtain hybrids. Two $600 \mathrm{~m}^{2}$ earth ponds $1.5 \mathrm{~m}$ in depth, were treated with dolomitic lime and flooded eight days before the introduction of the hybrids. The hybrids (voucher MHNU-1-1359) were raised for two years with biometry performed every two months, following the rules and procedures for the use of laboratory animals described by the Committee on Care and Use of Laboratory Animal Resources - National Research Council, USA (1996).The physical and chemical characteristics of the ponds' waters were: temperature $26.2 \pm 0.5$, dissolved oxygen $6.9 \pm 0.1$ $\mathrm{mg} / \mathrm{L}$ determined daily using an oximeter (YSI Professional Plus, Ohio, USA), pH $6.9 \pm 0.6$, total ammonia $0.15 \mathrm{mg} / \mathrm{L}$, nitrate $0.0 \mathrm{mg} / \mathrm{L}$, alkalinity $40-50 \mathrm{mg} \mathrm{CaCO} / \mathrm{L}$, and hardness $35 \mathrm{mg} \mathrm{CaCO} / \mathrm{L}$ determined weekly using a photometer (Eco-Check, Aquatic-Eco, Rock Hill, USA).

Morphological analysis of the gonads. Every two months during the two years of rearing, three apparently healthy specimens of each sex were randomly selected to carry out morphological analysis of the gonads. Fish were anesthetised with 2-phenoxyethanol (300 mg/L; Sigma Chemical Co, St. Louis, MO, USA) and the spinal cord sectioned for euthanasia before collection of tissues and organs. A total of 77 specimens were collected (41 females and 36 males). Despite not finding obvious sexual dimorphism, it was almost always possible to identify the females as the larger specimens and once the gonads were anatomically located, their shape, colour and appearance were described for both sexes.

Microscopic evaluation and histological analysis. In females, samples were taken from the middle and caudal portions of the ovary; and in males the cephalic, medial and caudal portions were sampled. Samples were fixed in $4 \%$ formalin $(\mathrm{pH} \mathrm{7.0)}$ and embedded in paraffin. Conventional histological analysis was carried out by taking serial sections of $5 \mathrm{~mm}$ and staining with standard haematoxylin-eosin solution. In order to evaluate the development of the gonads, micrographs were taken using an optical microscope (Nikon Eclipse E400, 40 and 100X, Kanagawa, Japan) with an integrated digital camera (Nikon Digital Sight, DS-5M). The images were analysed with the ACT-2U software (Nikon, ACT-2U Imaging Software).

Statistical analysis. Data were expressed as the mean \pm standard deviation. As data did not comply with the assumptions of distribution and homogeneity of variances to apply parametric tests, an ordinal Spearman correlation was performed to determine the relationship between the diameters of the oocyte and its nucleus. Subsequently, the Fisher's Least Significant Difference with Bonferroni correction was used to establish significant differences $(\mathrm{p}<0.05)$ between the gonadal variables (diameters of oocytes and their nuclei and diameter of the seminiferous tubules) with respect to the stage of biological development, species and the gonadal portion from which the sample was taken (cephalic, medium or caudal in males; medium or caudal in females).

\section{RESULTS}

The crossing of $P$. metaense and L. marmoratus generated a hybrid that accepted commercial feed and could be managed at stocking density of two fish $/ \mathrm{m}^{2}$. No mortality or cannibalism was observed under these conditions. After two years the females reached $2710 \pm 21.5 \mathrm{~g}$ in weight and $66.5 \pm 1.6 \mathrm{~cm}$ in total length, while the males reached 2175.3 $\pm 35.1 \mathrm{~g}$ and $56.3 \pm 2.5 \mathrm{~cm}$.

External reproductive characteristics of hybrids. Macroscopically, the hybrids were gonochoric with separate sexes, and the genital papillae of the two-year-old males were more pronounced and reddish than that of the females. The gonads were located in the lateral dorsal wall of the abdominal cavity, one on either side of the dorsal mesentery, under the swim bladder in the cephalic region and under the kidney in their caudal portions. In both sexes they were supported by connective tissue and the gastrointestinal tract is located underneath them. Their hue and vascularisation varied throughout the year according to the rainfall in the region. Pink and poorly vascularised gonads were commonly observed in the dry season, whereas during the rainy season the increase in vascularisation was evident and the ovaries turned yellowish. The males showed whitish and turgid digitiform testicles. 
RODRIGUEZ-PULIDO, J.; VILLAMIL-RODRIGUEZ, J.; MIRA-LÓPEZ, T.; CRUZ-CASALLAS, P. \& BALDISSEROTTO, B. Gonadal maturation in Pseudoplatystoma metaense $\times$ Leiarius marmoratus hybrids, (Siluriformes:Pimelodidae). Int. J. Morphol., 38(5):1405-1411, 2020.

Macroscopic description of ovaries. The ovaries of the hybrids were paired, saccular and elongated, with the right gonad being slightly larger. They were cystovarian oocytes and were identified in the abdominal cavity, dorsal to the intestine, under the swim bladder and kidney and connected to the roof wall of the coelomic cavity by the mesovarium. The ovary is vascularised by the ovarian artery, which co-
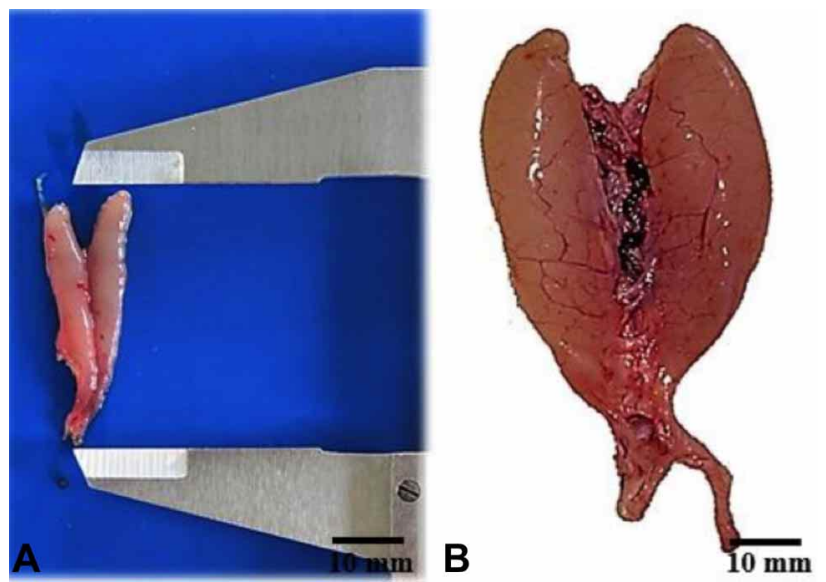

Fig. 1. Ovaries of hybrid P. metaense x L. marmoratus fish. A. Ovaries of 1-year-old specimens. B. Ovaries of 2-year-old specimens.
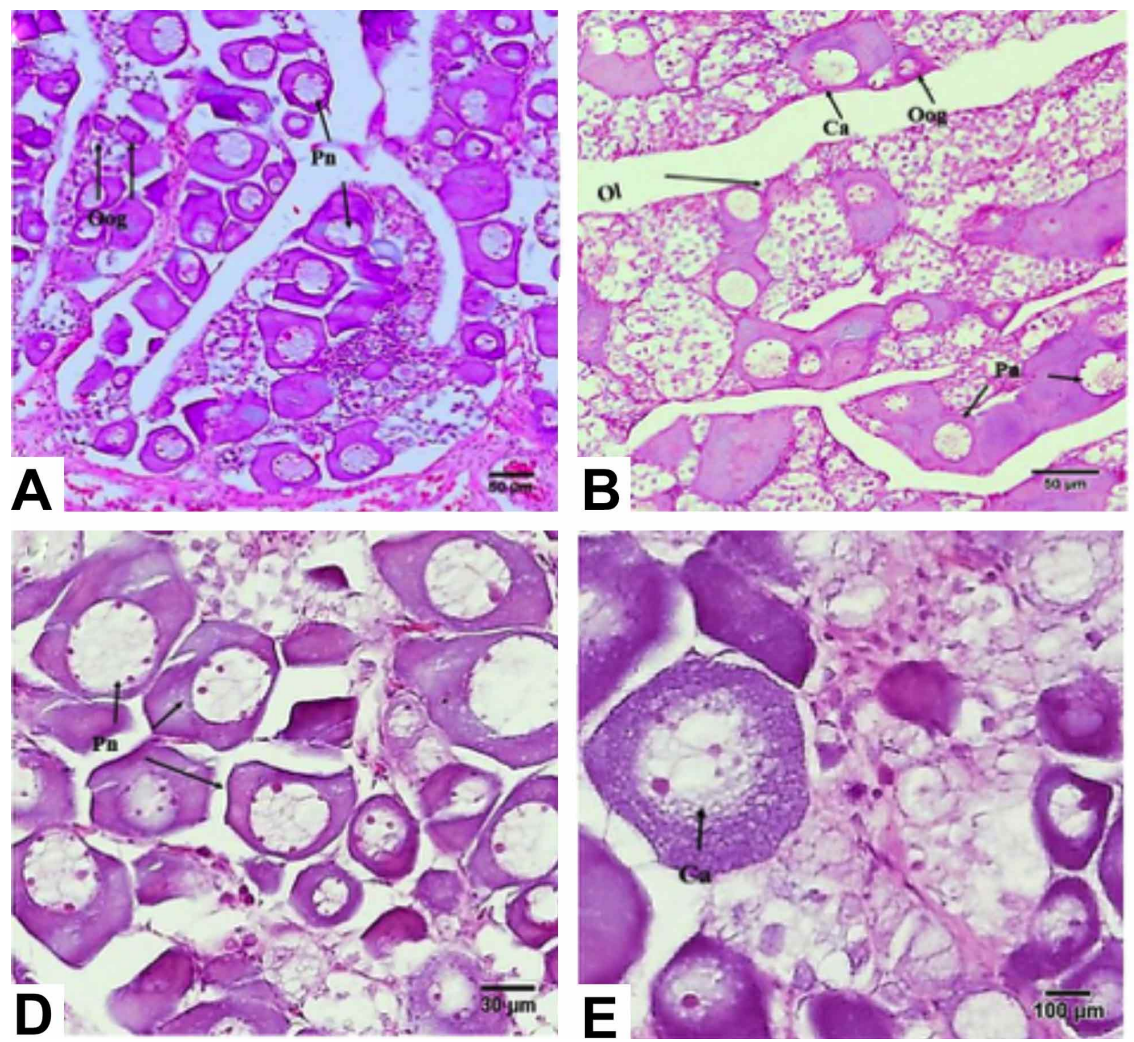

mes directly from the dorsal aorta, and blood is collected by the ovarian vein that drains into the hepatic portal vein. The degree of vascularisation was seen to be modified throughout the maturation processes and leads to a macroscopicallydetectable ovarian cycle (Fig. 1). The interior of the ovary contained numerous ovarian septa or lamellae of connective and muscular tissues that form an ovarian cortex, where oogonia and prefollicular cells were embedded in the germinal epithelium toward the basement membrane. Ovigerous lamellae projected from the tunica albuginea to the ovarian cavity.

Features of at least three phases of maturation were identified: the oogonia, perinucleolar and cortical alveolus. The oogonia was embedded in the ovarian stroma in cell nest, with the development of the cortical alveolus observed for the first 12 months. Maximum accumulation of yolk allowed the detection of oocytes with diameters up to 384.7 $\mathrm{mm}$ and an average of $284.9 \mathrm{~mm}$. The average diameter was $685.5 \mathrm{~mm}$ and the maximum diameter $1123.6 \mathrm{~mm}$ in the rainy season of the second year. The relationship between the accumulation of yolk and the changes in the nucleus and cytoplasm was clear. The oogonia have a ratio of 0.48 at the beginning of sampling, but at the end of the first year this

Fig. 2. Oocyte development of hybrid P. metaense x L. marmoratus fish. A. previtellogenic oocytes (20x), Oog: oogonia, Pn: Perinucleolar oocytes. B. Ovigerous lamella (Ol) showing abundant stroma of conjunctive tissue with previtellogenic follicles (20x), Ca: Cortical alveolus, Oog: oogonia, Pn: Perinucleolar oocytes. C. Oogonia $(\neq)(40 x)$, D. Perinucleolar oocytes (40x). E. Oocytes in the cortical alveolus (40x). F. Vitellogenic oocytes (Vt) (40x), N: Nucleus, n: nucleolus. 
value reached 0.28 for oocytes in the perinucleolar and cortical alveolar phases. The ratio was 0.23 at the second year, and vitellogenic oocytes in maturation processes were found.

Microscopic characteristics of the ovaries. The oogonia were ovoid, with a maximum size of $17.8 \mathrm{~mm} \pm 1.37$ and nuclei of $12.2 \mathrm{~mm} \pm 0.71 \mathrm{~mm}$. Previtellogenic oocytes in the perinucleolar phase were commonly observed in the first year. These oocytes were polyhedral in shape with large diameters $73.71 \pm 16.3 \mathrm{~mm}$ and a nucleus-cytoplasm ratio of 0.39 . The nuclei had little affinity for dye and oocytes contained one or two nucleoli. The radiated, acellular eosinophilic zone was observed between the follicular cells. Previtellogenic oocytes (diameter: $488.65 \pm 68.43 \mathrm{~mm}$ ) were only observed in the cortical alveoli in two-year-old females, and presented as numerous spherical structures that formed

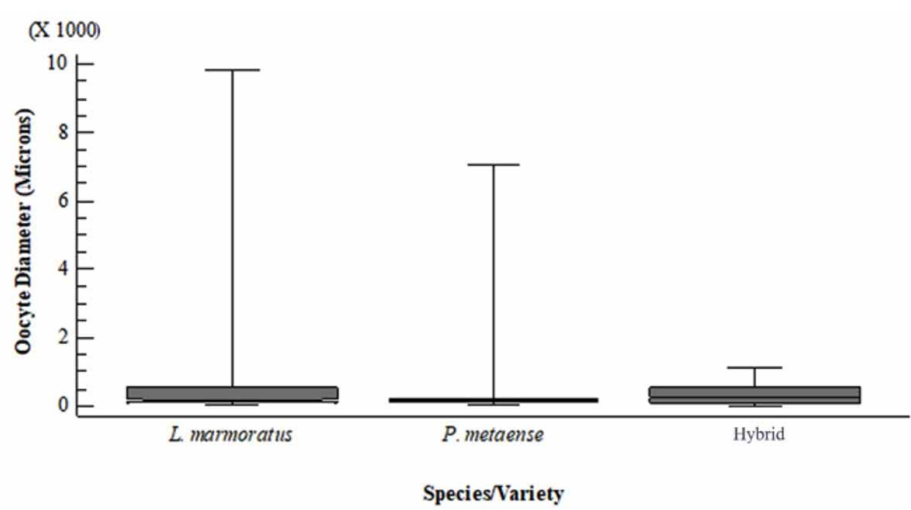

Fig. 3. Oocyte diameters of parent and hybrid fish. Comparison of the oocyte diameters of L. marmoratus, hybrid and P. metaense.
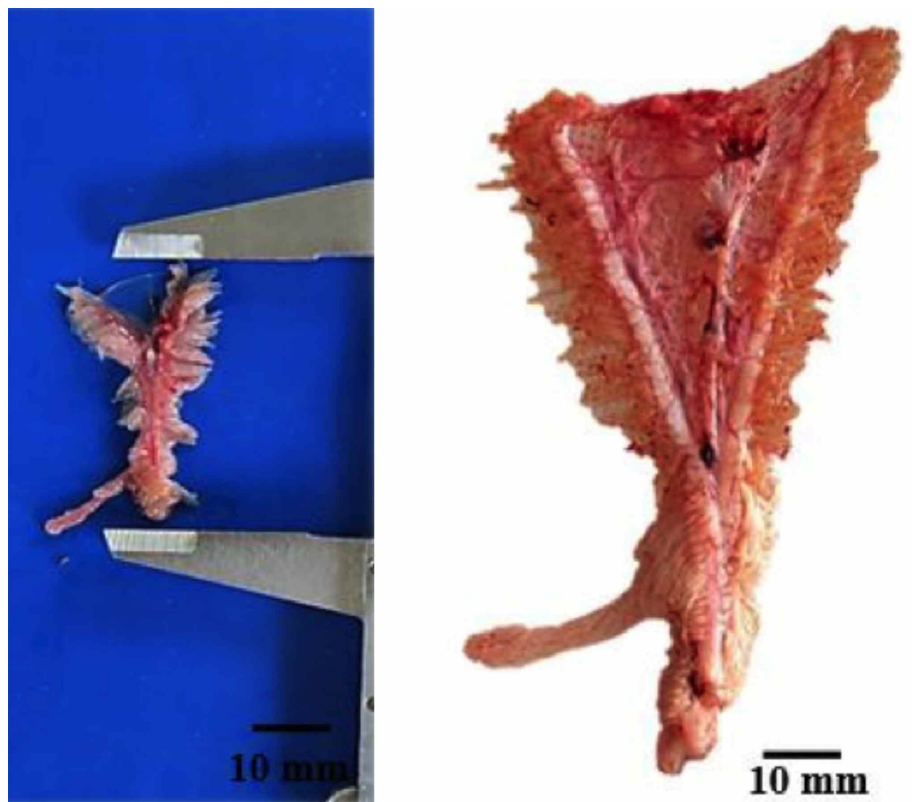

Fig. 4. Testes of hybrid P. metaense x L. marmoratus fish. A. Testes of 1 year-old specimens. B. Testes of 2-year-old specimens. acidophilic lipid vacuoles (Fig. 2). Striations were evident in the radiated area, and it was possible to differentiate the cells of the theca. The vitellogenic oocytes presented a nucleus-cytoplasm ratio of 0.227 and acidophilic platelets were found in the periphery of the cytoplasm. The irregularly contoured nuclei of the platelets were slightly eccentric with basophilic granulations and the maximum observed diameter was $1123.6 \mathrm{~mm}$ (Fig. 2). No ovulating females, atretic follicles or oocytes in reabsorption were detected. The smallest oocyte diameters were observed in hybrid fish, followed by L. marmoratus and P. metaense (Fig. 3).

Macroscopic description of testicles. The testes were two elongated, digitiform organs located in the dorsal wall of the abdominal cavity, and the right testicle was slightly larger than the left (Fig. 4). The cranial digitiform projections were found to be larger than the caudal projections, with whitish coloration. They were located under the swim bladder and the kidneys. The testicles were supported by the mesorchium at the roof of the cavity, and vascularised by the dorsal aorta which drains into the hepatic portal vein. The cephalic region was characterised by being independent, whereas the caudal region fused with the spermatic ducts which were visible on the ventral surface and formed a main spermatic duct that joins the urogenital papilla.

Microscopic characteristics of the testes. The testes were tubular, unrestricted spermatogonial type. The diameter of the tubules increased according to the region where the digitiform projections were located and also with maturation. In our observations, the diameters of the testicular tubules of the cranial region were greater than those of the caudal region, being $79.9 \mathrm{~mm}$ and $60.8 \mathrm{~mm}$ respectively. However, many tubules were anastomosed and free spermatozoa were found in the lumen and in the efferent ducts that converge in caudal-ventral direction to the spermatic duct (Fig. $5 \mathrm{a}-\mathrm{b})$, where glandular cells were also found. In the same way, the interstitial compartments of the testicle were characterised by having abundant connective tissue, smooth muscle and interstitial cells (Leydig cells). The germinative tissue was arranged in the walls of the tubules in testicular cysts containing spermatogonia, spermatocytes or spermatids (Fig. 6 a-d). Histological comparisons between the $P$. metaense and hybrid males revealed germinal tissue that was discontinuous and confined to the walls of the tubules and, after the first year, spermatozoa were observed in the lumen and in spermatic ducts. Therefore, it was not possible to find males in the empty phase. 


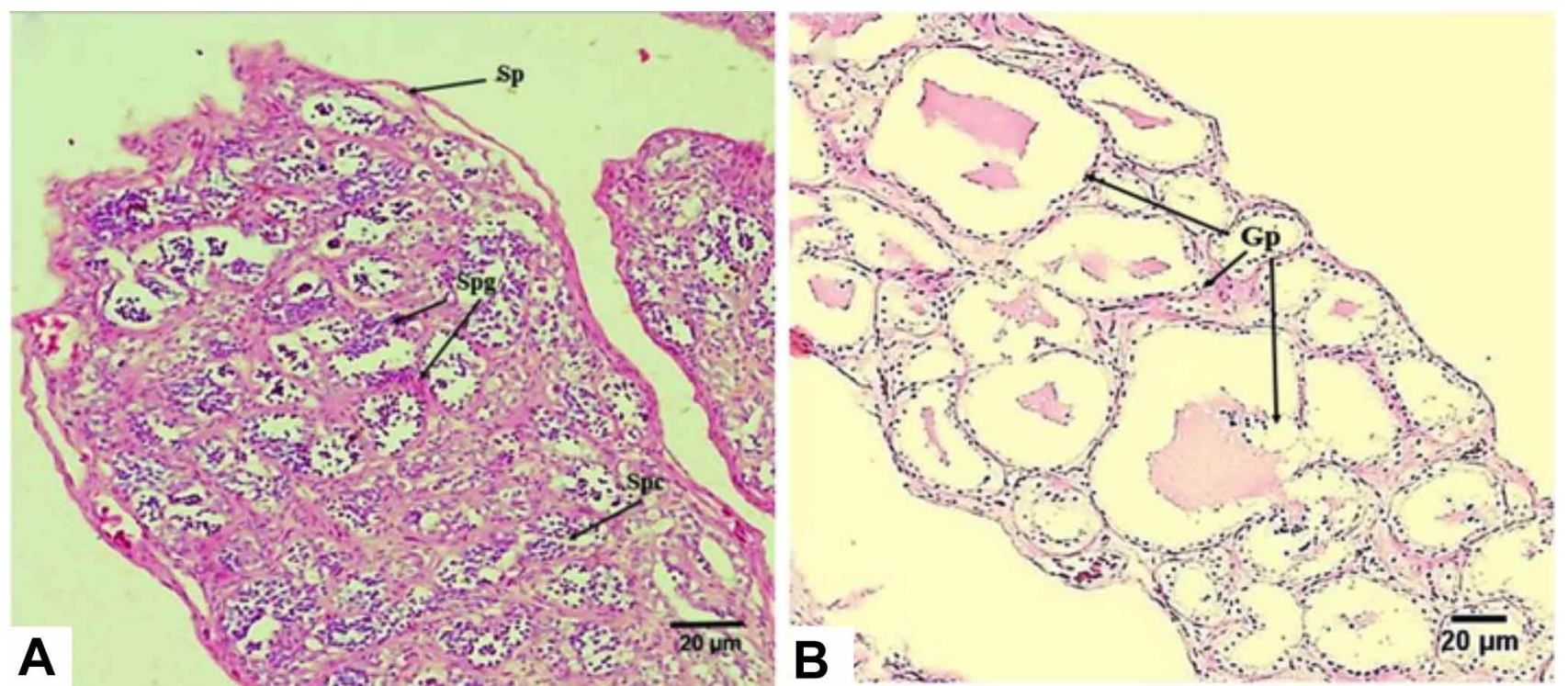

Fig. 5. Digitiform structure of testes of the P. metaense x L. marmoratus hybrid. A. Presence of spermatogenic cells (20x). B. Presence of protein material (20x). Sg: Spermatogonia, Spc: Spermatocytes, Spz: Spermatozoa, Gp: Glycoproteins.
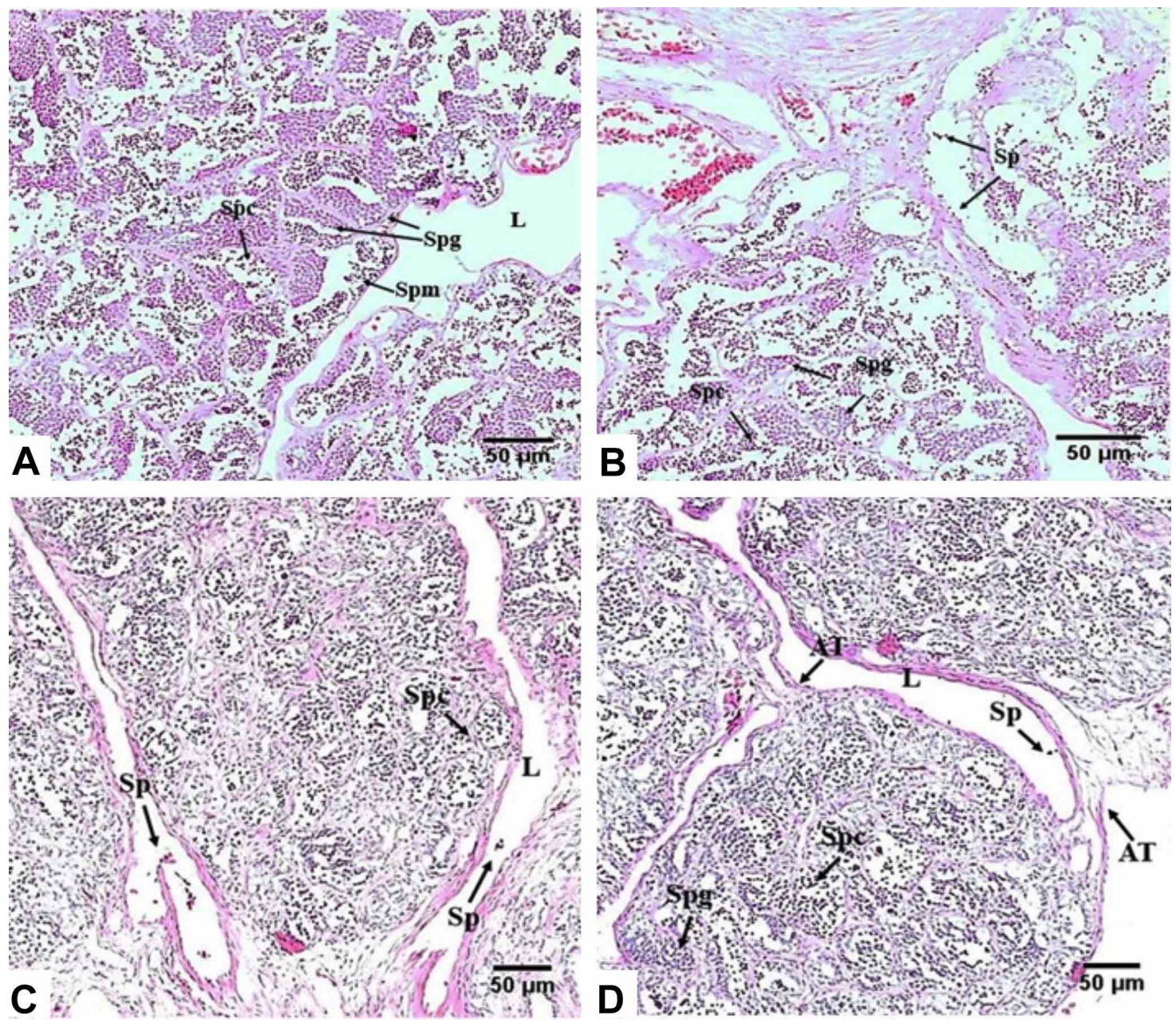

Fig. 6. Cells of the spermatogenic process A-D (20x) in hybrid P. metaense x L. marmoratus. Spg: Spermatogonia, Spc: Spermatocytes, Spm: Spermatids, Spz: Spermatozoa, L: Lumen, AT: Anastomosed tubules. 
Cystic mode spermatogenesis was seen in the fish of this study. Spermatogonia had diameters of $5.4 \mathrm{~mm} \pm 0.5$ $\mathrm{mm}$ and spermatocytes had diameters of $4.3 \pm 0.3 \mathrm{~mm}$. The spermatids (diameter $2.3 \pm 0.5 \mathrm{~mm}$ ) differed from the spermatozoa because they were inside the cysts; but their sizes, staining and rounded shape were equal to the spermatozoa, which were always found in the lumen of the tubules. A conspicuous seminal vesicle was absent. Some finger-like projections with stored glycoproteins and spermatozoa were evident in the caudal area; however, no microscopic evidence of the storage area or accumulation of acellular material was found.

The breaking of the cysts occurs at the beginning of maturation, releasing the spermatozoa into the lumen. All other stages are confined to the cysts, which were present at all times, indicating that males from the first year already had spermatozoa and making differentiation of the regression phase not possible. This was also observed in P. metaense, in which specimens reached maturity after a year and a half. The diameters of the tubules of two year old hybrid fish were significantly larger than those of one year old hybrid fish ( $<$ < 0.05) (Fig. 7), but no difference in the diameters was observed in the histological section (from higher to lower) of the cephalic, middle or caudal portions (Fig. 7). In spite of the above, glycoprotein material was observed in the spaces of the caudal tubules by histological examination.

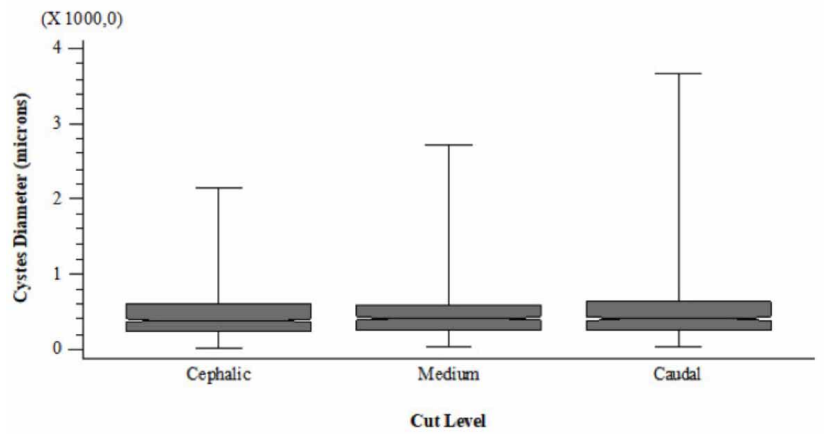

Fig. 7. Diameters of seminiferous tubules and comparison of tubule areas of different sections.

\section{DISCUSSION}

The hybrid obtained from the cross of female $P$. metaense and male L. marmoratus is a gonochoric pimelodid, morphologically functional and able to reproduce. The ovary of the hybrids reached maximum development during the rainy season, as has been reported for Eremophilus mutissi (Landines et al., 2017). The ovary is organised in ovigerous lamellae and oogonia, previtellogenic oocytes and mature oocytes were found, suggesting that the hybrid is group-synchronous according to the strategies reported for the parental species,
L. marmoratus (Mira-López et al., 2010) and P. metaense (before P. fasciatum) in ponds (Batlouni et al., 2006).

As the maximum oocyte size for hybrid females occurred during the highest period of rainfall, it is likely that their spawning time overlaps with that of the parent species (García-Dávila et al., 2015). Based on the oocyte characteristics, the fish could be pelagic and no parental care would be displayed (Marcano et al., 2007).

The macroscopic testicular morphology of the hybrids seems to be an intermediate of that reported for the parents, since they have some caudal projections with glycoproteins and spermatogonia that form nests embedded in an abundant connective tissue matrix, as reported for P. fasciatum (Núñez $\&$ Duponchelle, 2009). Some free spermatozoa were observed, but it was not possible to identify a seminal vesicle as has been described by Mira-López et al. for L. marmoratus. Despite this, hybrids presented abundant digitiform projections similar to those reported for Iheringichthys labrosus (Santos et al., 2001) and P. corruscans.

The microscopic conformation of the hybrids showed unrestricted spermatogonial testes with tubules that widened and anastomosed as gonadal maturity progressed, to form a tubular network, as observed in Diplacanthopoma brachysoma (Grier, 1981). This network contained numerous spermatozoa in the lumen, as well as spermatocysts in different stages of maturation in the interior and periphery. The anastomosed seminiferous tubules lead spermatozoa to the spermatic ducts, which is a characteristic organisation of the testes of some species (Parenti \& Grier, 2004) such as the Siluriformes Loricaria lentiginosa (Guimarães-Cruz et al., 2004) and Trachelyopterus striatulus (Santos et al., 2014). In addition, tubules filled with acidophilic acellular material (glycoproteins) were found (Fig. 5), similar to those which have been reported in P. fasciatum and L. marmoratus and in E. mutissi (Batlouni et al.; Mira-López et al.). This material has been described by Landines et al. to be seminal fluid for E. mutissi.

As with most Pimelodidae, the parental genera used in the present study share 56 chromosomes, and so the formation of hybrids is possible. Fertile hybrids have been reported among several species of this family, and even in distant lineages (Zhang et al., 2014) through external fertilisation and due to the high genomic plasticity. Unlike other vertebrates, in which the descendants of hybrids exhibit less fitness (Mallet), the hybrids of the current study do not fit the incompatibility theory cited by Rostand (1960) of BatensonDobzhansky-Mullet which states: "Hybrids will be sterile by regulatory genes and those related to development that should generate anomalies." 
The results of the present study indicate that hybrids can be capable of producing offspring, which lends increased weight to the concerns regarding the continued practice of hybridisation for commercial purposes in aquaculture. The reproductive potential of hybrids puts the natural populations of rivers at risk and could lead to the extinction of parental species by competition. It can be concluded that the production of hybrids must be managed and potentially regulated, in order to avoid affecting natural fish reserves.

ACKNOWLEDGMENTS. The authors thank to the University of Los Llanos (project VIAC-4811112014), Aquaculture Primavera for providing facilities and laboratories and Dr. Karen G. and Rodríguez C. from the Universidade Federal de São Carlos Brazil for histological processing of samples.

RODRIGUEZ-PULIDO, J.; VILLAMIL-RODRIGUEZ, J.; MIRA-LÓPEZ, T.; CRUZ-CASALLAS, P. \& BALDISSEROTTO, B. Maduración gonadal en híbridos de Pseudoplatystoma metaense x Leiarius marmoratus (Siluriformes: Pimelodidae). Int. J. Morphol., 38(5):1405-1411, 2020.

RESUMEN: El establecimiento de pautas para la gestión responsable en los sistemas de producción de peces requiere el conocimiento de la biología básica de los peces a criar. El objetivo de este trabajo fue determinar la capacidad reproductiva de los híbridos producidos por el cruce de hembras de Pseudoplatystoma metaense con machos de Leiarius marmoratus. Los machos presentaron un testículo espermatogonial digital no restringido que contiene dígitos caudales que producen glucoproteínas que no forman una vesícula seminal. Fue posible encontrar esperma libre en la luz de los túbulos y en los conductos. Se encontró que el ovario de las hembras era sacular y sincrónico con al menos tres grupos de ovocitos. En el primer año de vida, solo se encontraron oogonia hasta ovocitos previtelogénicos (alvéolo cortical de 284,9 $\pm 35,7 \mathrm{~mm}$ de diámetro). Después del segundo año, se observaron ovocitos vitelogénicos de $730 \pm 3,78 \mathrm{~mm}$ de diámetro. Los eventos de desarrollo gonadal de los híbridos indican que son animales sincrónicos gonocóricos. La maduración alcanza su punto máximo en la temporada de aguas altas, superponiéndose con las especies parentales. Por lo tanto, el escape de híbridos de cultivos de peces a los ríos puede aumentar el riesgo de cruces, introgresión genética o disminución de la capacidad reproductiva de las especies puras.

PALABRAS CLAVE: Desarrollo gonadal; Índices; Maduración sexual.

\section{REFERENCES}

Alves, A. L.; Varela, E. S.; Moro, G. V. \& Kirschnik, L. N. G. Riscos genéticos da produção de híbridos de peixes nativos. Palmas, Embrapa Pesca e Aquicultura, 2014. Available from: https://ainfo.cnptia.embrapa.br/digital/bitstream/item/ 131431/1/cnpasadoc3.pdf

Bartley, D. M.; Rana, K.; \& Immink, A. J. The use of inter-specific hybrids in aquaculture and fisheries. Rev. Fish Biol. Fish., 10:325-37, 2000.
Batlouni, S. R.; Romagosa, E. \& Borella, M. I. The reproductive cycle of male catfish Pseudoplatystoma fasciatum (Teleostei, Pimelodidae) revealed by changes of the germinal epithelium. an approach addressed to aquaculture. Anim. Reprod. Sci., 96(1-2):116-32, 2006.

do Prado, F. D.; Hashimoto, D. T.; Senhorini, J. A.; Foresti, F. \& Porto-Foresti, F Detection of hybrids and genetic introgression in wild stocks of two catfish species (Siluriformes: Pimelodidae): The impact of hatcheries in Brazil. Fish. Res., 125-126:300-5, 2012.

Dunham, R. A.; Ramboux, A. C. R. \& Perea, D. A. Effect of strain on the growth survival and sexual dimorphism of channel $\times$ blue catfish hybrids grown in earthen ponds. Aquaculture., 420-421(Suppl. 1):S20-S24, 2014.

Grier, H. J. Cellular organization of the testis and spermatogenesis in fishes. Am Zool., 21(2):345-57, 1981.

Hashimoto, D. T.; Mendonça, F. F.; Senhorini, J. A.; de Oliveira, C.; Foresti, F. \& Porto-Foresti, F. Molecular diagnostic methods for identifying Serrasalmid fish (Pacu, Pirapitinga, and Tambaqui) and their hybrids in the Brazilian aquaculture industry. Aquaculture, 32(1-2)1:49-53, 2011.

Landines, P. M. A.; Prieto, M. C.A.; Rodríguez, V. \& Rosado, P. R. Perfil de esteroides sexuales del Capitán de la Sabana (Eremophilus mutisii) durante un ciclo hidrológico completo. Rev. U. D. C. A. Act. Divulg. Cient., 20(1):43-50, 2017.

Mallet, J. Hybridization as an invasion of the genome.Trends Ecol. Evol., 20(5):22937, 2005.

Marcano, D.; Cardillo, E.; Rodriguez, C.; Poleo, G.; Gago, N. \& Guerrero, H. Y. Seasonal reproductive biology of two species of freshwater catfish from the Venezuelan floodplains. Gen. Comp. Endocrinol., 153(1-3):371-7, 2007.

Melo, B. F.; Dorini, B. F.; Foresti, F. \& Oliveira, C. Little divergence among mitochondrial lineages of Prochilodus (Teleostei, Characiformes). Front. Genet., 9:107, 2018

Mira-López, T. M.; Medina-Robles, V. M. \& Cruz-Casallas, P. E. Testicular morphology of yaque Leiarius marmoratus (Pisces: Siluridae) in maturity reproductive stage. Int. J. Morphol., 28(2):421-6, 2010.

Núñez, J. \& Duponchelle, F. Towards a universal scale to assess sexual maturation and related life history traits in oviparous teleost fishes. Fish Physiol. Biochem., 35(1):167-80, 2009.

Parenti, L. R. \& Grier, H. J. Evolution and phylogeny of gonad morphology in bony fishes. Integr. Comp. Biol., 44(5):333-48, 2004.

Rodríguez-Pulido, J. A.; Cruz-Casallas, P. E. \& Góngora-Orjuela, A. Hibridización de silúridos: una alternativa para la piscicultura con alto riesgo para la conservación de las especies nativas. Orinoquia, 20(I):62-8, 2016.

Rostand, J. Error and Deception in Science. Essays on Biological Aspects of Life. London, Hutchinson, 1960.

Santos, J. E.; Bazzoli, N.; Rizzo, E. \& Santos, G. B. Morphofunctional organization of the male reproductive system of the Catfish Iheringichthys labrosus (Lütken, 1874) (Siluriformes:Pimelodidae). Tissue Cell, 33(5):533-40, 2001.

Santos, M. L.; Sales, N. G.; Arantes, F. P.; Pessali, T. C.; Bazzoli, N. \& Santos, J. E. Anatomical and histological organization of the testes of the inseminating Catfish Trachelyopterus striatulus (Steindachner, 1877) (Siluriformes: Auchenipteridae). Anat. Histol. Embryol., 43(4):310-6, 2014.

Zhang, G.; Jia, X.; Yu, X.; Wang, P.; Yin, S. \& Zhao, C. Effect of water temperature on sex ratio and growth rate of juvenile Pelteobagrus fulvidraco, $P$. vachelli and hybrids [P. fulvidraco $\times$ P. vachelli]. Aquac. Rep., 3:115-9, 2016.

Zhang, Z. H.; Chen, J.; Li, L.; Tao, M.; Zhang, C.; Qin, Q.; Xiao, J.; Liu, Y. \& Liu, S J. Research advances in animal distant hybridization. Sci. China Life Sci., 57(9):889-902, 2014.

\section{Corresponding author:}

José Rodriguez-Pulido

Programa de Doctorado Ciencias Agrarias

Facultad de Ciencias Agrarias y Recursos Naturales

Instituto de Acuicultura de los Llanos, GRITOX

Universidad de los Llanos

Km 4 vía Puerto López

Villavicencio, Meta

Received: 02-04-2020

COLOMBIA

Accepted: 12-05-2020

Email: jarodriguez@unillanos.edu.co

https://orcid.org/0000-0002-6735-3885 